\title{
ANTONI MALCZEWSKI - DUCH ROMANTYCZNY ZANURZONY W TRADYCJI. O MARII
}

Gdy w 1825 roku trzydziestodwuletni Antoni Malczewski opublikował poemat Maria, to swym debiutem wpisywał się w trwający od pewnego czasu ferment dyskusji nad młodą poezją polską. Pojawił się bowiem na warszawskiej scenie literackiej jako nieznany autor zaledwie w trzy lata po tym, jak sympatycy romantycznych tendencji powitali ze szczególną atencją innego barda romantycznej muzy, pochodzącego z Litwy Mickiewicza. W trwającym wówczas twórczym fermencie (choć noszącym charakterystyczne dla czasów przełomu cechy niepewności ustaleń, kontrowersyjnych sądów i patetycznych uogólnień) Mickiewicz wybijał się stopniowo na czołowego poetę romantycznego. Debiutując kilka lat przed Malczewskim tomem Ballad i romansów (1822), poprzedzonym (co istotne) autorską przedmową teoretyczną O poezji romantycznej, otwierał nową epokę poezji polskiej. A przynajmniej składał w tej intencji interesujący projekt $\mathrm{w}$ postaci tomu poetyckiego o manifestacyjnie romantycznym charakterze w tematyce i w formie. Drugi tom Mickiewicza, o rok późniejszy, zawierający Grażynę oraz II i IV część Dziadów, ugruntowywał siłą rzeczy pierwszorzędną pozycję poety z Litwy na romantycznym parnasie. Warto dodać, iż także jego liczne pojedyncze wiersze, jak prowokacyjna Oda do młodości, Pieśń Filaretów czy Żeglarz, stawały się stopniowo swoistym stemplem romantyzmu w wersji Mickiewiczowskiej.

Słusznie zwrócił uwagę Bogusław Dopart, że w kontekście dokonań młodego Mickiewicza rok 1825 nie był dla autora Marii szczęśliwą datą debiutu. Według Doparta był to debiut niefortunnie ulokowany 
w czasie, gdyż Maria okazywała się utworem przedwczesnym i osamotnionym, pozostającym w cieniu szkoły litewskiej, podczas gdy głos tzw. szkoły ukraińskiej (Józef Bohdan Zaleski, Seweryn Goszczyński, Michał Grabowski) zauważono później i dołączono (Mochnacki) do tej grupy twórców również Antoniego Malczewskiego z jego poematem. Maria w momencie publikacji „nie utrafiła w swój czas także ze względu na stan krytyki romantycznej"1, która zasadniczo miała wówczas charakter postulatywny, zupełnie na uboczu zaś zostawiała kwestię interpretacji dzieła - i jeśliby odwrócić te dwa debiuty, to „podobny los spotkałby zapewne IV część Dziadów, gdyby pojawiła się ona jako publikacja skądinąd nieznanego autora"2. Można do tych uwag dodać na marginesie, że fakt osamotnienia Malczewskiego w ogólnej konstelacji wczesnoromantycznych propozycji i dyskusji znajdzie później swoiste echo w Norwidowskiej autorefleksji, mówiącej, iż bywają niefortunne zwroty historii, w których czytelnicy już nie oczekują nowych poetyckich objawień, więc jeśli wtedy pojawia się poeta, to ponosi klęskę z powodu braku rezonansu społecznego i jego los wypełnia się „w żywota pustyni”3. Norwid ten los skrzywdzonego przez historię pisarza dobrze rozumiał, a własną wspólnotę z Malczewskim w społecznym osamotnieniu wyraźnie odczuwał ${ }^{4}$.

Malczewskiego pojawienie się „nie w porę” dałoby się jednak rozpatrywać równie dobrze jako debiut nie przedwczesny, lecz spóźniony w stosunku do pierwszych lat ekspansywnej aktywności młodego pokolenia romantycznego i wobec erupcji poetyckich utworów (także spod znaku Mickiewicza) około roku 1822 i tuż później. Wśród tych

1 Bogusław Dopart, «Maria» Antoniego Malczewskiego - zagadnienie romantyzmu przedlistopadowego, w: Antoniemu Malczewskiemu w 17o. rocznice pierwszej edycji «Marii». Materiały sesji naukowej, Białystok 5-7 V 1995, pod red. Haliny Krukowskiej, Białystok 1997, s. 16.

2 Tamże.

3 Cyprian Norwid, [Klaskaniem mając obrzękłe prawice...], w: tegoż, Pisma wszystkie, zebrał, tekst ustalił, wstępem i uwagami krytycznymi opatrzył Juliusz W. Gomulicki, t. II: Wiersze. Część druga, Warszawa 1971, s. 15.

4 Pisał o tym Sławomir Rzepczyński w szkicu Za co Norwid cenit «Marię»?, w: Antoniemu Malczewskiemu w 170 . rocznicę..., dz.cyt. 
wczesnych debiutów pojawiły się na przykład poezje Józefa Bohdana Zaleskiego, też przybysza z Ukrainy, który zyskał sobie w epoce romantycznej opinię jednego z czołowych poetów (po Mickiewiczu). Zaleski opublikował swoje pierwsze utwory w „Pamiętniku Warszawskim” i w „Astrei” już w latach 1822-1823. Jego wizja Ukrainy, ludowo-sentymentalna, przesycona nutami tęsknoty, lecz w gruncie rzeczy słoneczna i optymistyczna, tętniąca rycerskim gwarem i bujną zielonością pełną leśnych rusałek i czarów - była na antypodach światoobrazu przedstawionego w Marii. Głos Zaleskiego przywołujący arkadyjski obraz kraju lat dziecinnych, wspomagany meliczną strukturą wierszy i odwołaniami do folkloru, odczytywany był jako poszukiwanie narodowych pamiątek w kulturze ludowej i w przeszłości polskiej Ukrainy. W recepcji pokolenia romantycznego lat przedlistopadowych projekt Zaleskiego stanowił „nie tylko poetyckie przeniesienie do miejsc utraconych a bliskich, lecz również [był] pewnym sposobem oglądania tych miejsc, patrzenia na nie z perspektywy dziecka - autentycznego posiadacza i mieszkańca tej Arkadii" Kreacja podmiotu o cechach naiwno-dziecięcych pozwalała poecie tworzyć mit idealnej przeszłości, była przywracaniem w poezji „raju utraconego" Ukrainy śpiewnej, magiczno-baśniowej, zanurzonej w zielonościach natury i jej tajemnicach.

Zaleski wprowadzał do poezji te romantyczne postulaty, które pozwalały mu nie odrzucać z kretesem, lecz przewartościować proponowany przez Brodzińskiego model poezji sielskiej i stapiać go $\mathrm{z}$ romantycznym historyzmem, $\mathrm{z}$ egzotyzmem oraz $\mathrm{z}$ wizją ukraińskiej natury widzianej przez pryzmat folkloru, ludowych wierzeń i legendarnych postaci. Autor ukraińskich dumek stawał się w ten sposób twórcą sentymentalnej wersji romantyzmu, takiej, która w latach pogłębiającej się świadomości niewoli narodowej łagodziła złe doznania rzeczywistości, przenosząc czytelników w przeszłość wyidealizowaną i poetycko stylizowaną. Jego projekt poezji wspierał

5 Zob. Barbara Stelmaszczyk-Świontek, Wstęp do: Józef Bohdan Zaleski, Wybór poezyj, oprac. B. Stelmaszczyk-Świontek, wybór, komentarz, oprac. Cecylia Gajkowska, BN I, nr 30, wyd. 3, zmien., Wrocław 1985, s. XX. 
sam Mickiewicz, dopatrujący się w poezji Zaleskiego cech romansu historycznego rodem $\mathrm{z}$ Waltera Scotta i wiążący z Zaleskim nadzieje na przyszłość polskiej poezji.

Maria w opisanym tu kontekście zapotrzebowania na „poezję serca" była utworem zasadniczo odmiennym, różnym od wszystkich wcześniejszych propozycji polskich poetów spod znaku romantyczności. Musiała wydawać się czymś niesłychanie ciemnym, wręcz czarnym - ścieżką bez wyjścia i bez nadziei.

Wracając do kwestii wyboru profilu, jaki przyjąć miała (czy mogła) polska poezja wczesnoromantyczna, trzeba zatrzymać się przy dwóch nazwiskach: Mickiewicza i Malczewskiego. Pojawienie się u progu epoki tych dwóch poetów dużej miary, z których każdy miał odmienną wizję roli tradycji i udziału historii w ludzkiej (i narodowej) egzystencji, mogło, jak twierdzą badacze, inaczej wpłynąć na wybór wzorca i kształt romantycznej literatury - niż to się stało. Wiele dyskutowano na temat tych dwu bardzo różnych propozycji literatury w latach przełomu. Były to, według określenia Marii Żmigrodzkiej: „dwa oblicza wczesnego romantyzmu”, dwa różne wzorce. W efekcie splotu wielu czynników wybrano wzorzec Mickiewiczowski, wcześniejszy, więc w istocie nie tyle „wybrano”, co uznano go, zanim pojawił się konkurent. Kilka lat różnicy w debiucie między obydwoma poetami zdaje się tu mieć, istotnie, duże znaczenie. Podobne do tej, jaka określiła miejsce Słowackiego na poetyckim forum, wobec „starszeństwa” Mickiewicza, o czym przekonująco pisał Kazimierz Wyka ${ }^{7}$. Zwykle bowiem w momencie, gdy przemiany kulturowe ulegają przesileniu na tyle ważkiemu, że coraz bardziej ostentacyjnie krystalizuje się nowa jakość epoki - wcześniej tylko zapowiadana licznymi symptomami, jakie prowadziły do kulminacyjnego zwrotu - następuje większa kumulacja i przyspieszenie zjawisk, które ów nowy kształt kultury zarysowują. Na gruncie literatury, jeśli wtedy, pod ciśnieniem oczekiwań, pojawia się silny, udany debiut, to

${ }^{6}$ Maria Żmigrodzka, Dwa oblicza wczesnego romantyzmu. Mickiewicz - Malczewski, „Pamiętnik Literacki” 1970, z. 1.

7 Kazimierz Wyka, Pokolenia literackie, Warszawa 1977, s. 229-231. 
z reguły pociąga on za sobą licznych wyznawców i staje się modelowym wzorcem, nadając kierunek dalszym przemianom. Działo się tak i u progu polskiego romantyzmu. Nowa, romantyczna formuła poezji wykluwała się i przedzierała $\mathrm{z}$ trudem przez wciąż jeszcze obowiązujące klasycystyczne zasady sztuki poetyckiej. Pokonywała opory i podlegała mediacjom..., drążąc w skale. Gdy objawił się Mickiewicz - młodzi przyjęli go z entuzjazmem zdolnym, jak się okazało, pokonać po pewnym czasie ostatecznie opór obozu klasyków. Po Mickiewiczu posypały się inne debiuty (Józef Bohdan Zaleski, Stefan Witwicki, Antoni Edward Odyniec, Aleksander Chodźko) twórców wpisujących się niejako w formułę Mickiewiczowskiej ludowości i wizji natury lub z tą formułą sąsiadujące. Bogusław Dopart wskazuje na „oswajającą i zacierającą nowatorskie tendencje prądu” rolę tych autorów, pozostających w polu oddziaływania zarówno Mickiewicza, jak Niemcewicza, czy też mediacyjnie „wypośrodkowanego" Brodzińskiego ${ }^{8}$, co oznaczało oscylowanie między: tradycją późnoklasycystyczną, sentymentalizmem i romantyzmem bliskim formule Ballad i romansów. Malczewski przybył niejako w środku fali oswajania Mickiewiczowskiego wzorca. Przybył więc może istotnie - „nie w porę”, za późno lub za wcześnie, wskutek czego pozostał w cieniu innego poety, który przed nim odważył się wystąpić przeciw zasadom poetyki późnego klasycyzmu.

Obok tej nasuwa się jednak refleksja zgoła inna: czy utwór taki jak Maria, przesycony pesymizmem i smutkiem, ukazujący krach ludzkich wartości, a w finalnym obrazie przedstawiający człowieka-bankruta, który, obłupany z tych wartości, staje się potencjalnym zbrodniarzem, byłby dla wczesnoromantycznej publiczności kiedykolwiek „w porę”? Czy ta publiczność była gotowa przyjąć ponurą diagnozę o świecie, w którym szlachetne serca „psują się w truciźnie przez jedną minutę", a jedyną pewną perspektywą w tym „posępnym malowidle", w melancholijnej pustce stepów jest stygmat przemijania i przechodzenia w śmierć? Czy to pierwsze pokolenie młodych Polaków, którym przyszło dorastać w niewoli, szukające nadziei na

\footnotetext{
8 Bogusław Dopart, «Maria» Antoniego Malczewskiego..., dz.cyt., s. 15.
} 
zmianę status quo przegranej właśnie Polski i na zmianę własnego losu straconego pokolenia - było skłonne i było w stanie przekroczyć pesymistyczny ton Marii i szukać w głębokich pokładach tej poetyckiej opowieści racji dających narzędzia do trwania, a tym bardziej do prze-trwania? Czy to pokolenie widziało w poemacie Malczewskiego argument, broń, taką jakość, która stać by się mogła wskazówką albo ekspiacją, albo pochodnią wyznaczającą drogę w przyszłość?

Pytam oczywiście o etyczne przesłanie Marii, o wartości ideowe dające nadzieję, której pierwsze pokolenie romantyków potrzebowało jak niezbędnego do życia pokarmu. Ale w podtekście pytam również o umiejętności rzetelnej analizy tekstu, co, jak wiemy ze świadectw, sprawiało odbiorcom i krytykom wczesnoromantycznej poezji - kłopot.

W późniejszej, XX-wiecznej i najnowszej recepcji, badacze romantyzmu konstatowali, że krytyka romantyczna była w ocenach poematu pełna ogólników i powierzchownych obserwacji. Zarzucano Marii fragmentaryczność, ciemność, zawiłość, odmienność zaś tej powieści poetyckiej od modelu Mickiewiczowskiego sprawiała, że kryteria ideowej i estetycznej odrębności na ogół rozpraszano, przyjmując schematycznie siatkę porównawczą, stosując, jak pisał Bogusław Dopart: „Zasady typologicznego czy chronologicznego systematyzowania zasobów nowej literatury (opozycja twórczości rodzimej i naśladowczej, podział na szkoły prowincjonalne, na epoki itp." jednak bez analitycznego podejścia do samego tekstu. Badacz ten, szczegółowo omawiający szerokie spektrum ocen romantycznej krytyki poświęconej Marii, pisał słusznie, że wobec tego „wyrażane przez interpretatorów oceny nie zobowiązują dzisiejszego badacza” ${ }^{10}$, „”ówczesna krytyka udziela niewielkiego wsparcia"11 we współczesnych badaniach nad poematem, gdyż oceny wówczas zapisane sygnalizują brak świadomości teoretycznej piszących, więc dzieło Malczewskiego,

9 Tamże, s. 11-12.

10 Tamże, s. 19.

11 Tamże, s. 20. 
wyjątkowo nowatorskie, pozostało dokonaniem „niemal odosobnionym, oryginalnym i wybitnym dziełem twórcy - samotnika"12.

Mimo początkowych nieporozumień i nieodczytania dzieła Malczewskiego, Maria odegrała ważną rolę w rozwoju romantycznej epiki poetyckiej ${ }^{13}$ i jako pierwsza polska powieść poetycka bez wątpienia oddziałała na innych twórców tego gatunku. Później stopniowo doceniano ją coraz bardziej, a począwszy od jej pierwszego monografisty Mikołaja Mazanowskiego, który nazywa poemat „prawym dziecięciem epoki”, odmiennym i wolnym od wpływu Mickiewicza, znaczenie Marii dla literatury romantycznej i jej oddzielność od projektu Mickiewicza staje się wspólnym ustaleniem badaczy. Tę odmienność podkreślali badacze dawniejszych i nowszych generacji - Józef Ujejski, Aleksander Brückner, a później również Maria Żmigrodzka, Halina Krukowska, Marian Maciejewski, Bogusław Dopart i inni ${ }^{14}$. Wbrew pierwszym, krytycznym opiniotwórcom tego dzieła było ono już w momencie opublikowania fenomenalnie nowoczesne, osiągające w zwartej, wyznaczonej przez zasadę symetrii strukturze wszystkie istotne wyznaczniki wstępującego romantyzmu, a jednocześnie wpisywało się oryginalnie w stworzony przez Byrona nowy typ epiki romantycznej, zarówno w planie narracji, jak i konstrukcji romantycznego bohatera.

Powieść poetycka jako nowy, synkretyczny gatunek był wytworem romantyzmu znacząco modernizującym zasady klasycznej epiki. Zainspirowany historyzmem Scotta, ale autorsko brawurowo zrealizowany po raz pierwszy przez Byrona, był wyzwaniem romantyków

\footnotetext{
12 Tamże, s. 11.

13 Zob. Ryszard Przybylski, Wstęp do: Antoni Malczewski, Maria. Powieść ukraińska, oprac. R. Przybylski, Warszawa 1976, s. 15.

14 Józef Ujejski, Antoni Malczewski (Poeta i poemat), Warszawa 1921; Aleksander Brückner, Wstęp do: Antoni Malczewski, Maria. Powieść ukrainska, ze wstępem i objaśnieniami A. Brücknera, Kraków 1925; Marian Maciejewski, Narodziny powieści poetyckiej w Polsce, Wrocław 1970; Maria Żmigrodzka, Dwa oblicza wczesnego romantyzmu..., dz.cyt.; Halina Krukowska, Noc romantyczna. Mickiewicz, Malczewski, Goszczyński. Interpretacje, Białystok 1985; Bogusław Dopart, «Maria» Antoniego Malczewskiego..., dz.cyt.; Jarosław Ławski, Marie romantyków. Metafizyczne wizje kobiecości: Mickiewicz-Malczewski - Krasiński, Białystok 2003.
} 
i wyzwaniem dla romantyków. W Polsce młodzi poeci czytali Byrona z zapałem i estymą, co potwierdzają źródła historyczne mówiące o lekturach zarówno młodego Mickiewicza, jak i Malczewskiego. Powtórzę dla porządku, że ten nowy gatunek synkretycznego romantyzmu przeciwstawiał się tradycji poematu bohaterskiego i dotychczasowym konwencjom organizacji epiki. Omówił tę kwestię ze znawstwem Ryszard Przybylski ${ }^{15}$, zestawiając na gruncie polskiej tradycji Marię z Barbarą Radziwiłłówna Alojzego Felińskiego i pokazując, w jaki sposób Malczewski przekracza i rozbija mechanizm klasycystycznego trzynastozgłoskowca: osłabiając średniówkę lub sytuując pauzę logiczną poza miejscem średniówki, tworząc więcej pauz w wersie i wręcz likwidując średniówkę - a wszystko w intensywności przekraczającej dopuszczalne w klasycystycznej regule odstępstwa od rytmicznego toku zasadniczego. W regule klasycyzmu odstępstwa te miały charakter przyzwolenia na jedynie chwilowe rozbicie monotonii wiersza, na jego urozmaicenie, u Malczewskiego zaś stawały się zasadą trwałą. Przybylski pokazał, jak romantyczny poeta odchodzi od efektów czysto retorycznych, stosując przerzutnie dynamizujące napięcie, i jak świadomie wprowadza język mówiony nieskrępowany retoryką - łamiąc tym samym ostentacyjnie podstawowe zasady epiki klasycystycznej.

A przecież nie z przypadku autor Marii, by opowiedzieć historię swoich bohaterów, pozostał jednak na poziomie podstawowym przy tradycyjnej wersyfikacji i rytmie trzynastozgłoskowca. Opowiadał wszak historię dawnej Polski, więc zachowując epicki, szeroki „oddech" tego wiersza, w pisywał własną opowieść w tradycję narodowej epiki. A że regularność średniówkowego toku wiersza rwał i „psuł”, to najwidoczniej miał w tym jakiś ważny cel. Nie chodziło mu o to, by odrzucić wersyfikację tradycyjnego poematu bohaterskiego, skoro tego nie uczynił, lecz by ją odkształcać. Wymienione przez Przybylskiego sposoby przekształceń pozwalają stwierdzić, że wpływają one na jakość narracji, a także w nowy sposób określają samego narratora. Osiągana bowiem dzięki tym zabiegom dynamizacja toku opowieści

15 Ryszard Przybylski, dz.cyt., s. 39-46. 
ujawnia zarazem pewien rodzaj napięcia, a nawet niepokoju tego, kto opowiada, lub jego nagłej niepewności co do przedstawianych postaci i zdarzeń. Ów narrator opisuje świat nie bez zaangażowania emocji i wyobraźni rozrywających spokojny tok wiersza, stawiane zaś pytania zdradzają, że brak mu „wszechwiedzy” klasycznego opowiadacza:

Tysiące piór, kamieni, w blask, w farby się stroi; Tysiące drobnych tęczy odbija się w zbroi;

A na ich bystrych oczach siedziało Zwycięstwo, A na ich serc opoce kwitły wierność, męstwo, A na czele tych szyków wyniosły młodzieniec. Lecz któż on? Jakiż chwały czy szczęścia rumieniec Lniane chcą cienić włosy? Och! Milszy sto razy Niż różowe porankiem natury obrazy, I słodszy, i jaśniejszy od chwały połysku Ten blask - co w jego serca żywi się ognisku Ten uśmiech $-[\ldots]^{16}$.

W efekcie tak prowadzonej narracji zostaje podkreślona indywidualna perspektywa oglądu świata i emocjonalne nacechowanie opisu, a zastosowany gramatyczny czas teraźniejszy ostatecznie „wyrzuca” narratora Marii z ram tradycyjnej epiki i z „wszechwiedzy”, jaką tradycyjny opowiadacz prezentował wobec opisywanego z zewnątrz i z perspektywy ex post - minionego świata. Malczewski (inaczej niż w poemacie klasycystycznym) czyni narratora obserwatorem ulokowanym wewnątrz przedstawianego świata i świadkiem zdarzeń dziejących się „teraz”, których ciąg dalszy jest mu nieznany. Z takiego osadzenia sprawozdawcy zdarzeń logicznie wynika jego niepewność i ograniczona wiedza o tych zdarzeniach. Przedstawiając zewnętrzne wyglądy świata i postaci, dąży Malczewski do ich głębszego wyjaśnienia, poszukując ukrytych uzasadnień tych wyglądów; przesuwa opis zjawisk zewnętrznych ku ich wewnętrznym źródłom - a więc ku

\footnotetext{
16 Antoni Malczewski, Maria. Powieść ukrainska, oprac. Ryszard Przybylski, Warszawa 1976, w. 145-155. Wszystkie następne cytaty z Marii podaję za tym wydaniem, zapisując po cytacie numer wersu.
} 
portretowi psychologicznemu, ku personifikacji i psychizacji abstrakcyjnych pojęć. Ów zwrot ku wewnętrznemu widzeniu (i słyszeniu) charakteryzuje też samego narratora, gdy wyostrzenie doznań zmysłowych prowadzi go do „otwarcia” pamięci oraz do uruchomionej przez pamięć wyobraźni i moralno-filozoficznej interpretacji widoków świata emocjonalnie odczytywanych:

Tylko wiatr szumi s m ut n i e uginając kłosy;

Tylko z mogił we stch nien ia i tych jęk spod trawy,

Co śpią na zwiędłych wieńcach swojej starej sławy.

Dzika muzyka - dziksze jeszcze do niej słowa,

Które Duch dawnej Polski potomności chowa -

A gdy cały ich zaszczyt, krzaczek polnej róży,

Ach! Czyjeż serce, czyje, w żalu się nie nuży? ${ }^{17}$.

[w. 24-30]

W przywołanym tu fragmencie w opis krajobrazu zostaje włączony, niejako naddany - portret samego opisującego: zostaje odsłonięta jego wiedza o tradycji, pamięć, przynależność do wspólnoty ludzi i niepokój o los tej wspólnoty podsycany żalem, iż rozwiewają się ślady jej historycznego trwania. Zgodnie z ideą romantycznego synkretyzmu ów portret narratora może być zbieżny z rysami autora, przynajmniej w wymiarze prezentacji historyczno-filozoficznej refleksji i w finalnym odsłonięciu światopoglądu. Zaznacza się przy tym emocjonalne nacechowanie opowieści, jakby ten, kto opowiada historię, zarazem odwzorowywał liryczne nachylenie tekstowego reprezentanta autora. Zbliżenie obydwu funkcji nie oznacza jednak ich pełnej identyfikacji. Pozostaje w mocy przeniesienie narratora w czas historyczny, w którym opisywane zdarzenia dzieją się „tu i teraz", przed oczyma tekstowego opowiadacza.

Przyjęty w definicji gatunku wyznacznik, że w powieści poetyckiej „przeniesienie” w dawność jest maską w celu ukazania współczesnych problemów - w poemacie Malczewskiego nieco się komplikuje.

17 Wyróżnienie moje - B.S. 
Pisał Marian Maciejewski, iż historyczna powieść poetycka, mimo odniesień do Scotta:

jest w gruncie rzeczy kryptowspółczesna. Figura maski spowija nie tylko poszczególne postaci, ale nakłada się jakby na całą warstwę fabularną, czyniąc z niej pretekst. Nieprzypadkowo mówiono w czasach powstania listopadowego, że słowo stało się ciałem, a Wallenrod Belwederem ${ }^{18}$.

Istotnie, taka interpretacja Konrada Wallenroda jest w pełni uzasadniona. Sądzę jednak, że w przypadku Marii funkcja historycznego ulokowania fabuły jest mniej pretekstowa, a otwarte zakończenie poematu rzutuje w przyszłość pytania o skutki zdarzeń dokonanych w opowiadanej przeszłości. Przestrzeń współczesna autorowi ma być odbiorcą dalszych, nieopisanych już w poemacie zdarzeń, losów, konsekwencji.

Mocno zaangażowany w rozwój literatury romantycznej Mochnacki pisał w swojej rozprawie O literaturze polskiej w wieku dziewiętnastym, będącej summą jego refleksji o najnowszej poezji, a przygotowywanej do druku w dniach powstańczego zrywu, w końcu listopada $1830^{19}$ :

Już te czasy przeminęły; wszystko się wkoło nas zmieniło. Co innego teraz mamy w myśli, w sercu, w staraniu. Jakże wielka zasługa poety! Postrzega w dali kształt historyczny - niknący, ledwo nie w nic się rozwiewający. Korzysta $\mathrm{z}$ chwili i nie daje się w niwecz obrócić pięknej pamiątce! Za sprawą tego, co przepadło w historii, nowe, poetyckie życie odzyskuje. Poezja drugim jest życia okresem, drugą koleją bytu. Jest tylko wyższą prawdą! Wszystko ziemianieje w powieści Malczewskiego ${ }^{20}$.

\footnotetext{
18 Marian Maciejewski, Powieść poetycka, hasło w: Słownik literatury polskiej XIX wieku, pod red. Józefa Bachórza i Aliny Kowalczykowej, Wrocław 1991, s. 754.

19 Ustalenia na temat czasu ukończenia rozprawy przez Mochnackiego zob. Ziemowit Skibiński, Przedmowa wydawcy, w: Maurycy Mochnacki, O literaturze polskiej w wieku dziewiętnastym, oprac. i przedmową poprzedził Z. Skibiński, Łódź 1985, s. 12 i nn.

20 Maurycy Mochnacki, O literaturze polskiej w wieku dziewiętnastym, dz.cyt., s. 115. Wszystkie następne cytaty z rozprawy Mochnackiego pochodzą z tego wydania; lokalizuję je w tekście głównym, podając po cytacie numer strony.
} 
A zatem romantyczny krytyk rozumiał sens Marii jako utrwalenie prawdy o sportretowanych przez poetę figurach dawnej Rzeczypospolitej szlacheckiej na tle ukraińskich stepów, w szumie wiatru i szczęku zbroi, zaangażowanych patriotycznie w „sprawie” z Tatarami - ku obronie ojczyzny. Zarazem jednak krytyk mówi wprost, że dawne dzieje i charakter dawnej Polski należą już do przeszłości i nie mają przełożenia na współczesne problemy Polaków („wszystko się wkoło nas zmieniło. Co innego teraz mamy w myśli, w sercu, w staraniu”). Jednocześnie Mochnacki wyraża przekonanie, że opowieść ta, przywracając do trwania dawny „kształt historyczny” Rzeczypospolitej, spełnia przede wszystkim funkcję „pięknej pamiątki”, uzyskującej drugie życie w poetyckiej realizacji.

Opinia Mochnackiego jest wiele mówiąca. Pozwala bowiem na wyciągnięcie wniosku, iż ten uważny czytelnik i krytyk, choć dostrzegał, że nakreślony przez Malczewskiego obraz XVII-wiecznej Polski nie jest jej idealizacją, lecz oddaje historyczną prawdę o minionych czasach, i że dociekliwa rzetelność autora poematu wydobywa na światło i cnoty, i wady Rzeczypospolitej, to jednak przesłanie dzieła dopasowywał do "potrzeb serca” współczesnych Polaków, przesuwając punkt ciężkości, czyli znaczenie zawartego w dziele obrazu: $\mathrm{z}$ wad na cnoty, ze „zdrożnego możnowładztwa” - na „rycerskie męstwo”. Pisał, że „szczery obraz” portretowanych w Marii bohaterów służył temu, by „cała przeszłość nasza sztuką czarnoksięską wzięła życie z rąk wielkiego artysty” (s. 116), ale chciał przez to rozumieć, iż sedno opowieści tkwi w upamiętnieniu polskiej chwały. Mochnacki czytał Marię spostrzegawczo, analitycznie, lecz chciał postrzegać poemat Malczewskiego przede wszystkim jako wydobywający z przeszłości pamięć o znanej w świecie zasłudze Polski w obronie Europy przed tureckim nawałem. Tę polską dzielność uczynił pointą i konkluzją najmocniejszą:

Wszystko się tam zeszło: nieukrócona duma arystokracji, zdrożne możnowładztwo z staroświecką cnotą i uczciwą godnością szlachcica pod skromną strzechą słomianą, toż rycerskie męstwo i charakter światowy, po wszystkie czasy daleko słynny dziejów polskich wedle 
tego, żeśmy stawili dzielny opór najazdom dziczy, która spustoszeniem oświacie europejskiej zagrażała. [s. 116]

Zwycięstwo Jana III pod Wiedniem nad Turkami było rzeczywiście głośną sprawą i uznaną zasługą Polski, ale w poemacie nie ma żadnego sygnału tę zasługę przypominającego czy eksponującego. W opisie walki z Tatarami można podziwiać Malczewskiego za znajomość tatarskich taktyk walki, ale całość wojennego wydarzenia zdaje się wskazywać nie tyle na „charakter światowy” polskiego czynu dla Europy (tu nawet nie wspomnianej), ile na „rycerskie męstwo” Miecznika i Wacława wraz z ich wojskiem. Ktokolwiek byłby najeźdźcą - cnota obywatelska nakazywała bronić ojczyzny. Ten nakaz moralny, opiewany już w pieśniach Kochanowskiego, ten ethos rycerski był pierwszą powinnością i podstawowym wyznacznikiem honoru Polaka i szlachcica. Wiedział to dobrze Miecznik - stary patriota, i wiedział Wacław - młody graf, i wiedział równie dobrze możny Wojewoda. I znów Mochnacki dobrze odczytał świetne zawęźlenie przez poetę intrygi Wojewody, wykorzystującego moc etosu i jego świętą siłę. Napisał bowiem Mochnacki, że Wojewoda mógł założyć bez wątpliwości, jaka będzie postawa Wacława i Miecznika, „gdy wzywa wspólna potrzeba" (s. 116). Mógł być pewien, że każdy z tych bohaterów zarzuci prywatne $z$ Wojewodą niesnaski i jeden wesprze drugiego, a obaj w imię etosu pójdą walczyć, zostawiając dom i Marię bez obrony. Wojewoda miał pewność, że tak się stanie, bo znał wartość rycerskiego etosu, którego pogwałcenie było niegodne honoru szlachcica, niegodne wspólnoty społecznej i rodzinnej. Pogwałcić etos - oznaczało okryć się hańbą, stracić duszę, sumienie i samego siebie. Ethos wyznacza zasady wspólnotowego bytu, jest etyczną podstawą zachowań ludzi objętych wspólnotą. Jego siła buduje zbiorową przestrzeń duchową i chroni wspólnotę przed rozpadem, a jednostki przed chaosem poczynań ${ }^{21}$. W tym kontekście nawet początkowe wątpliwości co do intencji Wojewody musiał Miecznik odrzucić, bo już sama nieufność, już rzucone na kogoś podejrzenie, że ten ktoś

21 Zob. Maria Ossowska, Ethos rycerski i jego odmiany, Warszawa 1986. 
mógłby nadużyć wartości „wspólnej potrzeby” obrony kraju - była myślą niegodną i hańbiącą.

Mochnacki dobrze rozumiał misterne nici doskonałej intrygi Wojewody, a jednak wolał nie analizować jej druzgocących skutków i pozostać przy stwierdzeniu, że przedstawione w dziele Malczewskiego zarówno złe, jak i dobre cechy minionej Polski jednako służą oży wieniu przez sztukę cennej narodowej pamiątki. W lekturze poematu przez Mochnackiego cnota obywatelska zdaje się mieć większe znaczenie niż pycha wielmoży. Nic zatem dziwnego, że w takim nachyleniu interpretacyjnym postać Wacława dużo mniej interesuje krytyka, który wycofuje tego bohatera na dalszy plan. Właściwie Wacław znika zupełnie w podsumowaniu analitycznej egzegezy poematu, gdy Mochnacki w finalnym wyliczeniu głównych bohaterów Marii pomija imię Wacława, jakby ta postać przeszkadzała przyjętej linii interpretacyjnej, jakby czyniła ją niepewną. Jakby Wacław nie pasował do „pięknej narodowej pamiątki”:

Taka jest powieść Malczewskiego o podniosłym Wojewodzie, o pięknej Marii i zacnym, starym Mieczniku. [s. 120]

Krytyk pomija również (jakby konsekwentnie wobec przyjętej tezy interpretacyjnej) tragiczne, a zarazem dramatyczne zakończenie poematu. Pomija rodzący się wtedy bunt Wacława i przekazaną czytelnikom przez narratora zapowiedź zemsty bohatera, która ma być dokonana na rodzinnym gnieździe. Zapowiedź zemsty, zbrodni, planowanego ojcobójstwa (którego czytelnik musi się domyślać, bo ten domysł ma swoje mocne uzasadnienie w tekście), ma być odwetem za zbrodnię popełnioną na żonie Wacława, ale też za zdradę. Mochnacki o tym pisze, ale nie wyciąga wniosków. Streszcza krótko „osnowę" opowieści, a o przygotowanym przez Wojewodę, perfidnie skrytym akcie mordu na Marii tak mówi:

Nie tak czyn krwawy, jako przyrządzenia mordercy wzbudzają grozę, kiedy [...] w skrytości myśli układa zabójstwo potajemnie, milczkiem, z tyłu godząc. [...] Nie śmierć, ale droga do śmierci, ale kręte do tego ścieżki, manowce sieją postrach. Wikła się myśl ludzka w tym 
labiryncie. [...] To czajenie się, uprzedzające skutek, jest na kształt mroku, jest jako ciemna strona f a $\mathrm{n} \mathrm{ta} \mathrm{z}$ j i. Jakaś opona, czarny kir zalega wtedy przestrzeń niezmierzoną między daleką chęcią, zawartą jeszcze w sercu, i jej dopełnieniem, między wyciągnięciem ręki i zadaniem ostatniego, śmiertelnego ciosu. Północna godzina Szekspira! [s. 112]

Mimo uderzającej przenikliwości i analitycznego talentu romantycznego krytyka, w cytowanym akapicie fakt zdrady i groza tego czynu (choć je Mochnacki dostrzega) zostają w gruncie rzeczy sprowadzone do efektów artystycznych, są uznane przede wszystkim za mistrzowsko zrealizowany pomysł, w którym artysta wykreował „ciemną stronę fantazji”, by osiągnąć szekspirowski pułap dramatyzmu w utworze. Słowa „fantazja” używa Mochnacki kilkakrotnie, nadając mu rangę romantycznej inwencji, upatrując w niej ważny punkt romantycznej poetyki.

Wszystko to prawda. Nic ująć! Maestria w konstrukcji intrygi i romantyczny napór ciemnej tajemnicy świata tworzą nastrój tego wielkiego, filozoficzno-moralnego poematu. Ale nie sposób, jak to czyni Mochnacki, przejść do porządku nad najbardziej zaskakującym, poetycko oryginalnym i filozoficznie niepokojącym zakończeniem poematu. Jest w tym zakończeniu otwarcie na przyszłość, bo jest zapowiedź zemsty właśnie na „nieukróconej dumie arystokracji”, na „zdrożnym możnowładztwie” - o czym krytyk milczy; jest w nim myśl odwetu, dzika reakcja spustoszonego człowieka, w którym zniszczono wartości, jakie dotychczas tworzyły w nim ład i sens jego istnienia. Jest w tym zakończeniu unicestwiony świat ludzkich wartości, a poemat otwiera się na przyszłość niewiadomą, ale w zapowiedzi zemsty niepokojąco ciemną, bez nadziei, skoro opartą o dokonane spustoszenie. Ta przyszłość rysuje się w mroku, w grozie zapowiadanego gwałtu „oko za oko”, który ma być dzikim odwetem, bo piękny młodzieniec, wierny sługa etosu, waleczny, jasny rycerz, co chciał zasłużyć na żonę rycerską dzielnością, co jak dziecko ufnie wierzył ludziom - nagle zbudził się starcem, który już wie, co to są świata "gorszkie, zatrute kołacze” (w. 667), i przejął od pacholęcia doświadczenie śmierci, która mu „zostawiła czarne w piersiach 
blizny” (w. 666), i staje się „ziemi ohydą” (w. 1377), gdyż jego dawna dobroć w świecie bez etosu straciła wszelkie uzasadnienie, straciła sens („Ach! pytaj raczej - na co dobroć się tu przyda”; w. 1378).

W poemacie Malczewskiego dopiero w finale Wacław staje się byronowskim buntownikiem. Polski poeta inaczej niż Byron konstruuje tę postać, nośną dla romantycznej formuły nowego typu bohatera. Wacław nie jest w opowieści bohaterem o nieznanej, tajemniczej biografii (jak u Byrona) i nie skrywa w tej biografii ciemnych tajemnic. Nie dotyczy go niejasność pochodzenia, nie przybywa $z$ odległych połaci świata, nie ma na swoim koncie zbrodniczej przeszłości ani nie jest już u progu opowieści człowiekiem „wyrzuconym za burtę” moralnych zasad świata; nie jest więc, jak w konstrukcjach byronowskich, moralnie dwuznaczny. Jest u siebie, w swojej ojczyźnie, w której należy do najwyższej klasy społecznej i ma ważny status społeczny (graf, syn Wojewody). Jest mężny i szlachetny - a mimo to zostaje zdławiony i zniszczony - nie przez tajemniczy los, nie przez nieodgadnioną Transcendencję, lecz przez ludzi, przez zdradę najwyższych wartości dokonaną we własnym gnieździe, co okazało się klęską wspólnotowej jedności i szekspirowską równią pochyłą, po której wszelkie dobro stacza się w nicość, a zostaje pustka, pustynia, śmierć.

Nie dostrzegam w poemacie Malczewskiego przypisywanego czasem autorowi Marii agnostycyzmu ${ }^{22}$, lecz raczej myśl niespokojną barokowej proweniencji, że Bóg jest nieodgadniony, a swe kary i nagrody zsyła w niewiadomym ludziom czasie („zsyła lub odwleka”). Sądzę też, że historia bohaterów żyjących w XVII-wiecznej Polsce nie służy Malczewskiemu jako maska historii, jak to słusznie zauważył Mochnacki, lecz stając się opowieścią niemal paraboliczną, jest zarazem wnikliwą historyczną analizą wad szlacheckiej Rzeczypospolitej - win, które niszcząc etos, doprowadziły do zniszczenia wspólnoty. Opowieść Malczewskiego staje się zarazem poetycką analizą przyczyn klęski, jej źródeł. Staje się oskarżeniem pychy feudalnych możnowładców, oskarżeniem wewnętrznych błędów Rzeczypospolitej. Wskazuje na

${ }^{22}$ Zob. Maria Żmigrodzka, Dwa oblicza wczesnego romantyzmu..., dz.cyt. 
winy ojców, którzy doprowadzili najpierw do upadku moralnego, a w konsekwencji również geopolitycznego.

Malczewski dedykował Marię Julianowi Ursynowi Niemcewiczowi. Jednak i w tym geście, podobnie jak z datą debiutu - nie trafił w odpowiedni czas. Jako pisarz starszego pokolenia Niemcewicz wydawał się adresatem mogącym dobrze przyjąć Marię. W swoich utworach odwoływał się bowiem Niemcewicz do poetyki ludowej dumy ukraińskiej zbliżonej do szkockich ballad (Alonzo i Helena), próbował przyswoić rodzimej literaturze ballady angielskie, czego efektem stały się jego elegijne dumy, łączące pierwiastki liryczno-refleksyjne z romansowymi. Wybór Niemcewicza na protektora opowieści wydaje się - i chyba przede wszystkim - dlatego uzasadniony, że Niemcewicz był jednym z patriotów zaangażowanych w czasach Sejmu Czteroletniego w próby naprawy Rzeczypospolitej, a w napisanych już w XIX wieku Uwagach nad upadkiem i charakterem narodu polskiego (1817) rozważał przyczyny upadku polskiej państwowości, dostrzegając i krytykując wady szlachty, które do upadku ojczyzny doprowadziły. Jest charakterystyczne, że „krytycyzm wobec szlachetczyzny [...] uległ jednak zahamowaniu u schyłku Królestwa Kongresowego wraz z nasileniem się - jak podaje Janusz Tazbir - antykonstytucyjnych represji" ${ }^{23}$. Wtedy to Niemcewicz zmienił front, zaprzestał oskarżeń, a w roku 1825 dokonał przeróbki swego Jana $z$ Tęczyna, „usuwając z powieści fragmenty, które mogłyby ukazać «złoty wiek» w ujemnym świetle"24. Potrzeba apoteozy przeszłości była w danym położeniu geopolitycznym Polaków tak ogromna, że ani (wcześniej) Niemcewicz, ani (później) Mochnacki - jako opiniotwórczy czytelnicy Marii - nie mogli się tej potrzebie przeciwstawić. Niemcewicz milczał. Mochnacki, naczelny krytyk romantyczny, nie chciał przejść milcząco obok Marii, obok tego dzieła niepospolitego, więc szukał w nim dla Polaków nie zwierciadła siebie samych, lecz raczej trudnej do znalezienia w poemacie chwały minionej Polski

\footnotetext{
23 Janusz Tazbir, Historia w powieści, hasło w: Słownik literatury polskiej XIX wieku, dz.cyt., s. 339 .

${ }^{24}$ Tamże.
} 
szlacheckiej. I tylko słowa hołdu, jaki chciał złożyć poecie, zabrzmiały w tekście Mochnackiego, mimo jego dobrej woli - paradoksalnie ironicznie:

żeby nie powiedzieli następcy nasi, że talent genialny jako cień przeszedł koło nas, a słowa jego razem z dźwiękiem ulatując w powietrzu się rozproszyły. [s. 117]

Paradoksalnie, ponieważ przesłanie poematu jednak się rozpraszało, przekształcane w narodową pamiątkę, w apoteozę polskich przeszłych dziejów - w imię szukania w przeszłości oparcia potrzebnego na czasy szoku porozbiorowego, na czasy klęski i zniewolenia. Lektura Malczewskiego miała służyć pokrzepieniu serc, choć Malczewski poeta takiego pokrzepienia w swym poemacie nie przekazywał.

\section{Summary \\ Antoni Malczewski as a Romantic Spirit Immersed into Tradition. On Maria}

The article offers a new reading of Antoni Malczewski's poetic novel Maria as an innovative - in terms of its form - work of early Romanticism. The author argues that the form of a classicist historical narrative was essentially modernized through the exemplary Romantic construction of the narrator (characteristic of syncretic genres in Romanticism) as well as an innovative - as far as Byron's model is concerned - project of a Romantic hero. Furthermore, Malczewski's narrative poem is presented by the author as the most accusatory text among the early Romantic new poetry works. Stelmaszczyk claims that it targets the socio-political system of old Poland that violated the balance of social forces and lead to the demise of ethos, which in turn resulted in the destruction of individual heroes, annihilation of moral values, and the emergence of deep pessimism that overshadowed the future fate of people. That pessimism is quoted as the reason behind the negative reception of Malczewski's narrative poem among his contemporaries.

Barbara Stelmaszczyk (Uniwersytet Łódzki) - dr hab. prof. UŁ (pracownik naukowo-dydaktyczny najpierw w Katedrze Literatury Romantyzmu i Literatury Współczesnej, następnie w Katedrze Literatury i Tradycji 
Romantyzmu). Autorka m.in. Wstępu do wydanego w serii „Biblioteka Narodowa" Wyboru poezyj Józefa Bohdana Zaleskiego (wyd. 3, zmienione, Wrocław 1985), a także monografii Istnieć w dwoistym świecie... Model człowieka i obrazy Boga w poezji Bolesława Leśmiana (Łódź 2009), oraz innych studiów i szkiców o poezji XIX i XX wieku (Ch. Baudelaire, A. Malczewski, A. Mickiewicz, C. Norwid, J. Słowacki, J.B. Zaleski; K.I. Gałczyński, S. Grochowiak, Z. Herbert, B. Leśmian, Cz. Miłosz); współautorka (wraz z Ziemowitem Skibińskim) tomu Kwiaty łódzkie. Antologia poezji o Łodzi (Łódź 1982). Tłumaczka z włoskiego tekstów filozoficznych Gianniego Vattimo. Współredaktorka pięciu zbiorowych tomów naukowych poświęconych literaturze, m.in. Rozjaśnianie ciemności. Studia i szkice o Norwidzie (Kraków 2002; wraz z Jackiem Brzozowskim). Prowadziła również cykle wykładów o literaturze polskiej na uniwersytetach w Mediolanie, Bratysławie i Wilnie. Interesuje się zagadnieniem podmiotowości nowoczesnej, zwłaszcza autobiografizmu, autonarracji i modelami konstruowania podmiotu autorskiego w poezji. 